\title{
TRIP11/PDGFRB Fusion Protein
}

National Cancer Institute

\section{Source}

National Cancer Institute. TRIP11/PDGFRB Fusion Protein. NCI Thesaurus. Code C99687.

A fusion protein encoded by the TRIP11/PDGFRB fusion gene. This protein is comprised of the $\mathrm{N}$-terminal leucine zipper domain of the thyroid receptor-interacting protein 11 fused to the C-terminal transmembrane and cytoplasmic domains of the beta-type platelet-derived growth factor receptor protein, including the tyrosine kinase domain. 